\title{
PELAKSANAAN PROGRAM CORPORATE SOCIAL RESPONSIBILITY (CSR) COCA-COLA AMATIL INDONESIA SOUTHERN SUMATRA PADA MASYARAKAT DESA SUKANEGARA KECAMATAN TANJUNG BINTANG
}

\author{
Oleh: \\ Hinfa Mosshananza \\ Program Studi Administrasi Publik, Universitas Tulang Bawang Lampung \\ e-Mail: hinfamosshananza@gmail.com
}

\begin{abstract}
ABSTRAK
Permasalahan penelitian menunjukkan bahwa Pelaksanaan CSR Coca-Cola Amatil Indonesia (CCAI) Southern Sumatra. Seharusnya dilakukan secara merata sesuai kebutuhan dan kemampuan masyarakat sekitar. Namun realitasnya CCAI Southern Sumatra yang berada di Lampung Selatan tidak melaksanakan program CSR-nya secara merata pada masyarakat Desa Sukanegara untuk Tahun periode 2017. Tujuan penelitian adalah untuk mengetahui pelaksanaan CSR CCAI dan kendala-kendala dalam pelaksanaannya. Metode yang digunakan adalah penelitian deskriptif dengan pendekatan kualitatif.

Hasil penelitian menunjukkan bahwa CCAI dalam melaksanakan program-program CSR, CCAI menggunakan beberapa program yaitu: Program Penanaman 1.000 Pohon, Program Donor Darah, Program Coke Farm dan Program Pemberian Hewan Qurban. Adapun kendala dalam pelaksanaan program CSR CCAI; Pertama, tidak terlaksananya penanaman 1.000 pohon di dua dusun yang berada di Desa Sukanegara, Kedua, sulit mengajak masyarakat untuk berpartisipasi dalam program donor darah, Ketiga, lambatnya proses edukasi yang diserap oleh para petani dalam memahami materi yang diberikan mitranya dari Unila, Keempat, jumlah petani/masyarakat yang ikut dalam program Coke Farm hanya berjumlah 4 orang.
\end{abstract}

Kata kunci: pelaksanaan, corporate social responsibility (CSR)

\section{PENDAHULUAN \\ 1.1. Latar Belakang}

Pelaksanaan tanggung jawab sosial perusahaan atau Corporate Social Responsibility (CSR) bukanlah hal yang baru di setiap perusahaan dan telah berkembang sejak lama. Pada saat itu, dicetuskan agar pemerintah melakukan intervensi yang bertujuan memperluas ruang lingkup CSR. Ruang lingkup CSR tidak hanya mencakup tanggung jawab korporasi kepada pemegang saham (shareholders), tetapi juga kepada pekerja, konsumen, pemasok, masyarakat, terciptanya udara bersih, air bersih, dan dan konstituen lain di mana perusahaan melakukan aktivitas usahanya.

Pemerintah akhirnya mempertimbangkan dinamika sosial kemasyarakatan baik pada tingkat lokal maupun global, maka pembuat Undang-Undang menetapkan CSR yang pada awalnya sebagai tanggung jawab moral 
menjadi tanggung jawab hukum dengan menormakannya ke dalam berbagai ketentuan peraturan perundang-undangan. Kemudian dinormatifkannya prinsip-prinsip CSR tersebut, sehingga sifat tanggung jawabnya dari sukarela (voluntary) berubah menjadi kewajiban (mandatory), yang selanjutnya ditetapkanlah mengenai CSR dalam Undang-Undang Nomor 40 Tahun 2007 tentang Perseroan Terbatas.

Sesuai dengan undang-undang CSR yang dikemukakan di paragraf sebelumnya, bahwa perusahaan yang berkaitan dengan sumber daya alam diwajibkan melaksanakan tanggung jawab sosial dan lingkungan. Hal tersebut sesuai dengan objek penelitian yang penulis pilih yaitu Coca-Cola Amatil Indonesia (CCAI) Southern Sumatra, perusahaan tersebut menggunakan sumber daya alam berupa air tanah di Desa Sukanegara Kecamatan Tanjung Bintang.

Dalam pelaksanaan CSR CCAI di Desa Sukanegara yang terdiri dari 6 (enam) dusun. Tidak semuanya merasakan program CSR CCAI. Terdapat dua dusun yaitu Dusun Gunung Besi dan Dusun Talang Bayur yang belum merasakan program CSR. Hal tersebut bisa menimbulkan kecemburuan sosial apabila pihak CCAI sebagai unsur pelaksana tidak melakukan secara merata.

\subsection{Rumusan Masalah}

Rumusan Masalah dalam penelitian ini adalah Bagaimana Pelaksanaan Program Corporate Social Responsibility (CSR) Coca-Cola Amatil Indonesia (CCAI) Southern Sumatra di Desa Sukanegara ? dan Apakah Kendala Pelaksanaannya ?

\subsection{Pengertian Pelaksanaan \\ (Implementasi)}

Menurut J. Salusu (1996: 409) pelaksanaan adalah "Seperangkat kegiatan yang dilakukan menyusul satu keputusan. Dapat juga dikatakan sebagai operasionalisasi dari berbagai aktivitas guna mencapai suatu sasaran tertentu".

Soewarno Handayaningrat (1996:26) mengemukakan bahwa "Pelaksanaan adalah usaha agar semua anggota kelompok suka melaksanakan tercapainya tujuan dengan kesadaran dan berpedoman kepada perencanaan dan pengorganisasian".

Dengan memperhatikan beberapa pendapat para ahli tentang pengertian pelaksanaan (implementasi), dapat diambil kesimpulan bahwa pelaksanaan adalah serangkaian kegiatan dan tindakan yang dilakukan oleh semua pihak yang terlibat dalam organisasi, dalam upaya mencapai tujuan organisasi.

\subsection{Pengertian Program}

Menurut Sumar dalam Saleha (2005: 26), program didefinisikan sebagai usaha-usaha jangka panjang yang mempunyai tujuan meningkatkan pembangunan pada suatu sektor tertentu untuk mencapai beberapa proyek.

Menurut Jones (1996:67), Program adalah rencana yang telah diolah dengan memperhatikan faktor-faktor kemampuan ruang waktu dan urutan penyelenggaraannya secara tegas dan teratur sehingga menjawab pertanyaan tentang siapa, dimana, sejauhmana dan bagaimana. Program juga merupakan tahap-tahap dalam penyelesaian yang berisi langkah-langkah yang akan dikerjakan untuk mencapai tujuan yang diinginkan.

\section{LANDASAN TEORI}




\subsection{Pengertian Corporate Social Responsibility (CSR)}

Menurut Pasal 1 angka 3 Undang-Undang Nomor 40 Tahun 2007 tentang Perseroan Terbatas (disingkat UUPT) menegaskan bahwa :

"Tanggungjawab sosial dan lingkungan adalah komitmen perusahaan untuk berperan serta dalam pembangunan ekonomi berkelanjutan guna meningkatkan kualitas kehidupan dan lingkungan yang bermanfaat, baik bagi perusahaan sendiri, komunitas setempat, maupun masyarakat pada umumnya."

Menurut Farmer dan Hogue dalam Azheri (2011:27) merumuskan CSR sebagai :

"Social responsibility action by a corporation are action that, when judged by society in the future, are seen to have been maximum help in providing necessary amounts of desired goods and service at minimum financial and social cost distributed as equitably as possible. CSR adalah komitmen perusahaan untuk mampu memberikan apa yang masyarakat inginkan. Jadi perusahaan tidak hanya dapat menyediakan barang dan memberikan pelayanan terhadap pembeli barang saja, tetapi juga ikut membantu memecahkan masalah-masalah seputar masyarakat.”

\subsection{Prinsip-prinsip Corporate Social Responsibility (CSR)}

Menurut Nor Hadi (2011:59-60) ada Tiga Prinsip CSR diantaranya yaitu :

a. Sustainability, berkaitan dengan bagaimana perusahaan dalam melakukan aktivitas (action) tetap memperhitungkan keberlanjutan sumberdaya di masa depan. Keberlanjutan juga memberikan arahan bagaimana penggunaan sumberdaya sekarang tetap memperhatikan dan memperhitungkan kemampuan generasi masa depan. Dengan demikian, sustainability berputar pada keberpihakan dan upaya bagaimana society memanfaatkan sumberdaya agar tetap memperhatikan generasi mendatang.

b. Accountability, merupakan upaya perusahaan terbuka dan bertanggungjawab atas aktivitas yang telah dilakukan. Akuntabilitas dibutuhkan, ketika aktivitas perusahaan memengaruhi dan dipengaruhi lingkungan eksternal. Konsep ini menjelaskan pengaruh kuantitatif aktivitas perusahaan terhadap pihak internal dan eksternal.

c. Transparency, merupakan prinsip penting bagi pihak eksternal. Transparansi bersinggungan dengan pelaporan aktivitas perusahaan berikut dampak terhadap pihak eksternal. Transparansi merupakan satu hal yang amat penting bagi pihak eksternal, berperan untuk mengurangi asimetri informasi, kesalahpahaman, khusunya informasi dan pertanggungjawaban berbagai dampak dari lingkungan.

\section{METODOLOGI PENELITIAN} 3.1.Jenis penelitian

Peneliti menggunakan metode penelitian kualitatif. Penelitian Kualitatif dalam penelitian yang telah dilakukan adalah bersifat deskriptif. deskriptif artinya dalam bentuk pembahasan, menjelaskan hubungan antara perusahaan terhadap masyarakat menguraikan data, berupa kata-kata, gambar dan bukan angka-angka. Diperoleh dari berbagai tekhnik pengumpulan data seperti wawancara dan observasi (Moleong 2002 : 11).

Tujuan dari penelitian kualitatif deskriptif ini adalah membuat deskripsi, gambaran atau lukisan secara sistematis, faktual, akurat mengenai fakta-fakta, sifat-sifat serta hubungan antar fenomena yang diteliti. Subjek penelitian dalam penelitian ini adalah 
Pelaksana CSR CCAI, Masyarakat Desa yakni; Kepala Desa Sukanegara, serta masyarakat yang merasakan program corporate social responsibility akan tetapi tidak semua dijadikan sumber informasi melainkan hanya mereka yang memenuhi kebutuhan data dalam penelitian.

Sumber data yang diperoleh melalui sumbersumber, yaitu : Teknik Observasi, Wawancara, Dokumentasi. Teknik analisis data dalam penelitian ini setelah data- data penelitian terkumpul, peneliti akan menganalisis data-data tersebut dengan teknik analisis data menurut Miles \& Huberman (1992) dalam Emzir (2012:129) yang tahapannya adalah sebagai berikut: Reduksi Data, Penyajian Data, Penarikan Kesimpulan.

\section{PEMBAHASAN}

Program Corporate Social Responsibility (CSR) Coca-Cola Amatil Indonesia Southern Sumatra (CCAI) merupakan suatu bentuk program sosial yang dilakukan oleh pihak swasta seperti perusahaan CCAI yang terletak di kawasan industri Tanjung Bintang Kabupaten Lampung Selatan. Pelaksanaan program CSR CCAI selalu rutin setiap tahun dilaksanakan, khususnya di sekitar perusahaan CCAI beroperasi. Pelaksanaan tersebut setiap tahunnya dilakukan oleh mereka.

Pelaksanaan program CSR CCAI awalnya dilakukan berdasarkan kesukarelaan perusahaan kepada masyarakat sekitarnya, namun seiring perubahan zaman dan sesuai dengan undang-undang yang berlaku, maka pelaksanaan program CSR yang tidak hanya perusahaan CCAI saja melainkan juga perusahaan-perusahaan lain menjadi sebuah kewajiban setiap perusahaan untuk melaksanakan CSR, khususnya perusahaan yang menggunakan sumber daya alam (SDA).
Untuk melaksanakan program CSR, perusahaan CCAI dari tahun-ketahun telah melaksanakan berbagai kegiatan program CSR. Program CSR yang mereka lakukan tidak hanya dilakukan di sekitar perusahaan saja, namun mereka melakukan kegiatan CSR-nya dimanapun yang menurut mereka pantas dilakukan kegiatan CSR sesuai daerah yang benar-benar memerlukan bantuan-bantuan sosial. Program CSR yang dilakukan perusahaan biasanya berupa program sosial dan lingkungan. Mereka dalam pelaksanaannya melibatkan banyak pihak, terutama para karyawan yang bekerja di CCAI, masyarakat sekitar, Aparatur Pemerintah setempat, dan instansi/lembagalembaga lain yang bermitra dengan perusahaan CCAI.

Berdasarkan uraian di atas, dapat diketahui bahwa Program-program CSR Coca-Cola Amatil Indonesia (CCAI) Southern Sumatra sebagai berikut :

\subsection{Program Penanaman 1000 Pohon}

Program tersebut telah terlaksana di Desa Sukanegara. Penanaman tersebut melibatkan masyarakat di 4 (empat) dusun yang berada di Desa Sukanegara, yakni Dusun Banjarsari, Kemang, Sukamulyo, dan Perum Sukanegara. Pelaksanaan program penanaman 1.000 pohon tersebut, melibatkan beberapa karyawan CCAI, masyarakat sekitar perusahaan, aparatur pemerintah setempat, dan pada saat itu pihak perusahaan mengundang Bupati Lampung Selatan dan Kapolsek Tanjung Bintang untuk terlibat dalam pelaksanaan penanaman 1.000 pohon di Desa Sukanegara.

Seperti yang dijelaskan oleh Kepala Desa Sukanegara, Bapak Heri Tamtomo: 
“..Pelaksanaan penanaman 1.000 pohon tersebut tentunya bermanfaat bagi lingkungan Desa Sukanegara ini menjadi lebih hijau dan tidak gersang, karena sebelumnya desa kami sangat gersang dan jarang ada tumbuhtumbuhan besar seperti pohon mahoni. Sekarang ya sudah lumayanlah keadaannya, terutama lingkungan sekitar perusahaan juga ditanami pohon-pohon. Masyarakat di sini juga lebih peduli lingkungan setelah adanya program tersebut. "(Wawancara tanggal 17 Februari 2018)

Manfaat yang dirasakan masyarakat khususnya di Desa Sukanegara, merupakan sebuah dampak dari pelaksanaan program penanaman 1.000 pohon. Keadaan lingkungan mereka menjadi lebih ramah lingkungan dengan berkurangnya polusi udara yang disebabkan pabrik-pabrik yang berada di daerah kawasan industri khususnya daerah Tanjung Bintang. Mengenai pemeliharaan pohon-pohon tersebut sebenarnya CCAI telah menghimbau kepada masyarakat saat pelaksanaan program tersebut, agar masyarakat dan pihak CCAI bersama-sama merawat serta memelihara pohon Mahoni yang telah tumbuh di sepanjang jalan di Desa Sukanegara secara bersama-sama.

Dalam pelaksanaan penanaman 1.000 pohon yang dilakukan CCAI, ditemukan kendala dalam pelaksanaannya. Kendala yang penulis ketahui melalui wawancara bahwa, kendala tersebut adalah saat proses pelaksanaan penanaman 1.000 pohon tidak semua masyarakat Desa Sukanegara ikut dalam pelaksanaan tersebut. Pelaksanaan tersebut hanya melibatkan empat dusun yaitu Dusun Banjarsari, Perum Sukanegara, Kemang dan Sukamulyo. Namun, dusun yang tidak ikut dalam pelaksanaan program penanaman 1.000 pohon hanya dua dusun, yakni Dusun Gunung Besi dan Talang Bayur. Hal ini merupakan sebuah kendala bagi CCAI untuk melaksanakan program CSR untuk Desa Sukanegara khususnya bagi masyarakat yang tinggal di Desa Tersebut. Penyebab kendala tersebut karena jarak dua dusun yang tidak terlibat dalam pelaksanaan penanaman 1.000 pohon terlalu jauh dengan perusahaan, sehingga CCAI merasa kesulitan untuk menjangkau daerah tersebut walaupun dalam posisi dua dusun tersebut masih satu bagian dari Desa Sukanegara.

\subsection{Program Donor Darah}

Pelaksana CCAI telah melaksanakan kegiatan sosial donor darah di Desa Sukanegara. Pelaksanaan tersebut melibatkan mayoritas karyawan CCAI yang merupakan masyarakat dari ke empat dusun yang terlibat dalam pelaksanaan kegiatan sosial donor darah, yakni Dusun Banjarsari, Kemang, Sukamulyo, dan Perum Sukanegara. Kegiatan tersebut juga dihadiri oleh Camat Tanjung Bintang, Kapolsek Tanjung Bintang, dan Masyarakat Desa lainnya.

Dalam pelaksanaan donor darah di Desa Sukanegara, CCAI memiliki tujuannya yaitu mengajak masyarakat dan karyawan perusahaan CCAI yang berada di Desa Sukanegara untuk sukarela mendonorkan darahnya kepada pihak PMI setempat yang bekerja sama dengan PMI. Kegiatan tersebut adalah suatu bentuk kepedulian CCAI untuk membantu masyarakat yang akan membutuhkan darah di PMI. Proses yang dilakukan pihak CCAI saat pelaksanaan 
CSR, mereka sebelumnya terlebih dahulu menghubungi pihak PMI untuk mengadakan kegiatan donor darah, apabila semua setuju untuk pelaksanaannya, maka pihak perusahaan melalui Kepala Desa Sukanegara untuk memberi tahu kepada masyarakat Desa Sukanegara siapa saja yang sukarela akan mendonorkan darah mereka pada PMI yang saat itu bekerjasama dengan CCAI.

Seperti yang dijelaskan oleh Pelaksana CSR CCAI, Bapak Basuki menyatakan bahwa:

"Program donor darah, hasil yang diperoleh adalah kami memperoleh cukup banyak pendonor setiap kami mengadakan kegiatan donor darah dengan pihak PMI, saat pelaksanaan di Desa Sukanegara kami memperoleh 80 kantong darah. Selain itu juga hasilnya bagi masyarakat adalah khususnya masyarakat Desa Sukanegara yang bekerja sebagai karyawan CCAI rutin untuk menyumbangkan darahnya ke PMI setiap kami adakan program donor darah yang berkala antara 2 hingga 3 kali dalam setahun." (Wawancara tanggal 3 Februari 2018)

Program CSR CCAI seperti donor darah juga terdapat sedikit kendala. Seperti sulitnya mengajak masyarakat untuk terlibat dalam kegiatan donor darah, kemudian juga kurang pedulinya masyarakat sekitar terhadap kegiatan kemanusiaan tersebut yang diselenggarakan CCAI. Masyarakat Desa Sukanegara yang ikut dalam kegiatan donor darah ini mayoritas mereka yang bekerja di CCAI. Program donor darah ini dalam pelaksanaan teknisnya tidak ditemui kendala, karena dari pihak PMI telah menyiapkan semua peralatanperalatan yang dibutuhkan bagi para pendonor.

\subsection{Program Coke Farm}

Salah satu program Corporate Social Responsibility (CSR) CCAI yang berfokus pada bidang pertanian yakni, Program Coke Farm. Program Coke Farm ini bertujuan untuk mengonversi lahan kosong ke daerah pertanian yang lebih produktif, menyebarkan teknik pertanian yang profesional, menciptakan manfaat ekonomi bagi masyarakat lokal, dan membantu mengurangi jejak karbon perusahaan. Coke Farm tersebut terletak di belakang pabrik CCAI di Tanjung Bintang tepatnya di Desa Sukanegara yang luasnya sekitar $1.000 \mathrm{~m} 2$.

Agar tercapainya tujuan tersebut, CCAI bermitra dengan Unila sebagai konsultan di bidang pertanian. Kemitraan diantara keduanya, yakni guna merealisasikan dengan membudidayakan sayuran hidroponik, sayuran organik, pembudidayaan jamur tiram, pemrosesan kompos dari limbah teh "Frestea", serta penanaman ribuan pohon keras untuk penghijauan. Proses pelaksanaannya melibatkan masyarakat sekitar dan kelompok tani untuk mempelajari pembudidayaan tanaman hidroponik dan organik dengan cara yang profesional, namun mudah diaplikasikan bagi petani.

Dalam program coke farm tersebut telah menghasilkan beberapa manfaat khususnya pada masyarakat yang terlibat langsung dalam proses program coke farm. Selama program tersebut berlangsung selama setahun telah mengubah cara bertani masyarakat yang sebelumnya belum memiliki basic pertanian di bidang pertanian hidroponik, setelah mengikuti program coke farm tersebut mereka menjadi mengerti bagaimana pengelolaan dan 
menanam tanaman pertanian hidroponik.

Selain itu dampak yang diperoleh masyarakat Desa Sukanegara, khususnya masyarakat yang terlibat dalam program tersebut dapat menularkan/mengajarkan ilmunya kepada masyarakat lainnya yang ada di Desa Sukanegara, supaya mereka mengerti juga tentang cara bertani tanpa menggunakan pestisida. Program tersebut juga bertujuan untuk mengubah lahan kosong yang tidak produktif menjadi produktif setelah program coke farm dilaksanakan, lahan tersebut menjadi produktif dan lahan yang kosong tersebut ditanami seperti buah melon, jagung manis, kangkung, tomat, bayam dan lain-lainnya.

Seperti yang dijelaskan Petani Coke Farm, yang merasakan secara langsung dampak dari program tersebut, Ibu Rodiah yaitu:

"Hasilnya sesuai program coke farm itu sendiri kami memperoleh manfaat dari hasil pertanian yang kemudian kami jual sendiri dan keuntungannya kami yang merasakannya. Kami juga merasa lebih mengerti dan paham tentang pertanian hidroponik dan caracara bertani yang benar sehingga kami bisa memperoleh tanaman pertanian yang subur-subur seperti buah melon, jagung manis, kangkung, tomat, bayam dan lain-lainnya." (Wawancara tanggal 2 Maret 2018)

Kemudian mengenai kendala dalam pelaksanaan program coke farm. Kendala yang dihadapi saat pelaksanaan tersebut ada beberapa masalah yakni, SDM para petani yang sulit sekali menerima masukan saat diberikan pendidikan mengenai pertanian hidroponik, proses daya tangkap tiap petani berbeda-beda. Kemudian kendala yang kedua adalah petani yang sebelumnya ikut bergabung tersebut lebih terbiasa menggunakan pestisida saat bertani, namun pihak CCAI dalam program coke farm mereka tidak memperbolehkan menggunakan pestisida pada tanamantanaman, sayur-sayuran serta buahbuahan. Hal tersebut membuat para petani mengalami kesulitan saat praktek langsung di lapangan, ditambah lagi tanaman yang tidak menggunakan pestisida ini mudah sekali terkena hama tanaman sehingga rusak. Selain itu juga faktor cuaca juga menjadi penghambat dalam pelaksanaan program coke farm yang saat itu rumahan untuk pembudidayaan jamur tiram rusak parah, roboh terkena tiupan sejenis angin puting beliung.

\subsection{Program Pemberian Hewan Qurban}

CSR CCAI telah melaksanakan program pemberian hewan qurban di Desa Sukanegara. Sesuai dengan rencana program CSR CCAI yang setiap tahun memberikan sumbangan 2 (dua) ekor sapi saat Hari Raya Idul Adha. Program pemberian hewan qurban yang dilakukan CCAI kepada masyarakat Desa Sukanegara merupakan program CSR di sektor agama. Pelaksanaan tersebut melibatkan karyawan CCAI dan masyarakat yang berada di dekat perusahaan dari 4 (empat) dusun di Desa Sukanegara, yakni Dusun Banjarsari, Kemang, Sukamulyo, dan Perumsukanegara.

Dalam pelaksanaan program pemberian hewan qurban yang diberikan kepada masyarakat Desa Sukanegara setiap hari raya Idul Adha merupakan sebuah program rutin tahunan pada sektor 
agama. Mengenai kendala pada program pemberian hewan qurban ini, tidak ditemukan kendala. Semua berjalan sesuai rencana awal program CCAI dibentuk yakni; setiap tahun CCAI memprogramkan Desa Sukanegara didonasikan 2 (dua) ekor sapi setiap tahun. Program tersebut biasanya dilakukan di pabrik CCAI dan kadang juga di masjid Desa Sukanegara. Pemberian hewan tersebut bertujuan untuk memberikan dampak positif perusahaan kepada masyarakat sekitar bahwa, CCAI peduli terhadap suatu acara hari raya khususnya umat Islam. Seperti yang di ungkapkan oleh pelaksana CSR CCAI Bapak Basuki yaitu:

“ ...untuk program pemberian hewan qurban, kami sebagai pelaksana tidak mengalami kendala. Semua berjalan sesuai rencana program yang kami buat. Program tersebut setiap tahunnya memberikan 2 (dua) ekor sapi kepada masyarakat Desa Sukanegara. Semua tepat sasaran dan program telah berjalan efektif serta berhasil." (Wawancara tanggal 3 Februari 2018)

\section{PENUTUP}

\subsection{Kesimpulan}

Berdasarkan hasil analisis data dan pembahasan yang telah dikemukakan pada bagian terdahulu, ,maka dapat disimpulkan bahwa Coca-Cola Amatil Indonesia (CCAI) Southern Sumatra sudah melaksanakan Program Corporate Social Responsibility (CSR) pada Masyarakat Desa Sukanegara pada periode Tahun 2017 yaitu : Program Penanaman 1.000 pohon, Program Donor Darah, Program Coke Farm, Program dan Pemeberian Hewan Qurban. Dalam pelaksanaan di antara program-program CSR-nya terdapat beberapa kendala, yaitu saat pelaksanaan Program Penanaman 1.000 pohon terdapat kendala seperti tidak terlaksanannya pada dua dusun yang ada di Desa Sukanegara yaitu Dusun Gunung Besi dan Talang Bayur, CCAI merasa kesulitan dalam mengajak masyarakat sekitar untuk ikut berpartisipasi dalam pelaksanaan program donor darah dan mayoritas karyawan yang bekerja di CCAI ikut dalam pelaksanaan tersebut, pada pelaksanaan program coke farm, lambatnya proses pelajaran yang diserap oleh para petani dalam memahami materi yang diberikan mitranya dari Unila dan hanya melibatkan 4 orang masyarakat Desa Sukanegara terhadap pelaksanaan program coke farm.

\section{DAFTAR PUSTAKA}

Azheri, busyra. 2011. Corporate Social Responsibility. Rajawali Pers. Jakarta.

Emzir. 2012. Metodologi Penelitian Kualitatif: Analisis Data. Jakarta : PT. Rajagrafindo Persada.

Hadi, Nor. 2011. Corporate Social Responsibility. Graha Ilmu. Yogyakarta.

Handayaningrat, Soewarno. 1996. Pengantar Studi Ilmu Administrasi dan Manajemen, Jakarta: PT. Toko Gunung Agung.

Jones, Charles O, 1996. Pengantar kebijakan publik. Jakarta: PT.Raja Grafindo

Moleong, Lexy. J. 2002. Metodologi Penelitian Kualitatif. Remaja Rosda Karya. Bandung. 
Undang-Undang Nomor 40 Tahun 2007

Tentang Perseroan Terbatas. 